Historic, Archive Document

Do not assume content reflects current scientific knowledge, policies, or practices. 



\section{Sediment Vields from High Mountain Watersheds,}

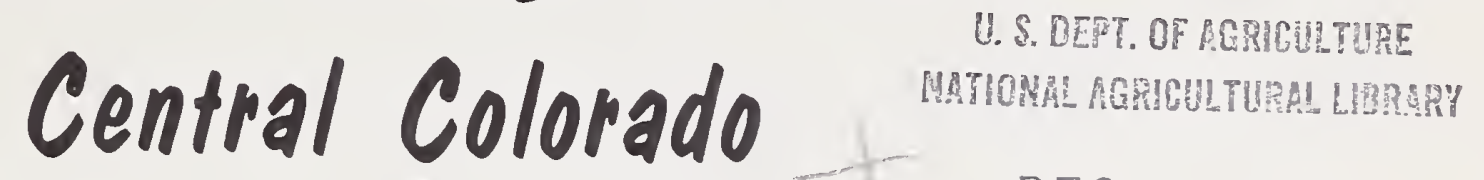

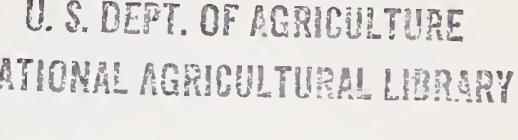

EEC - 7966

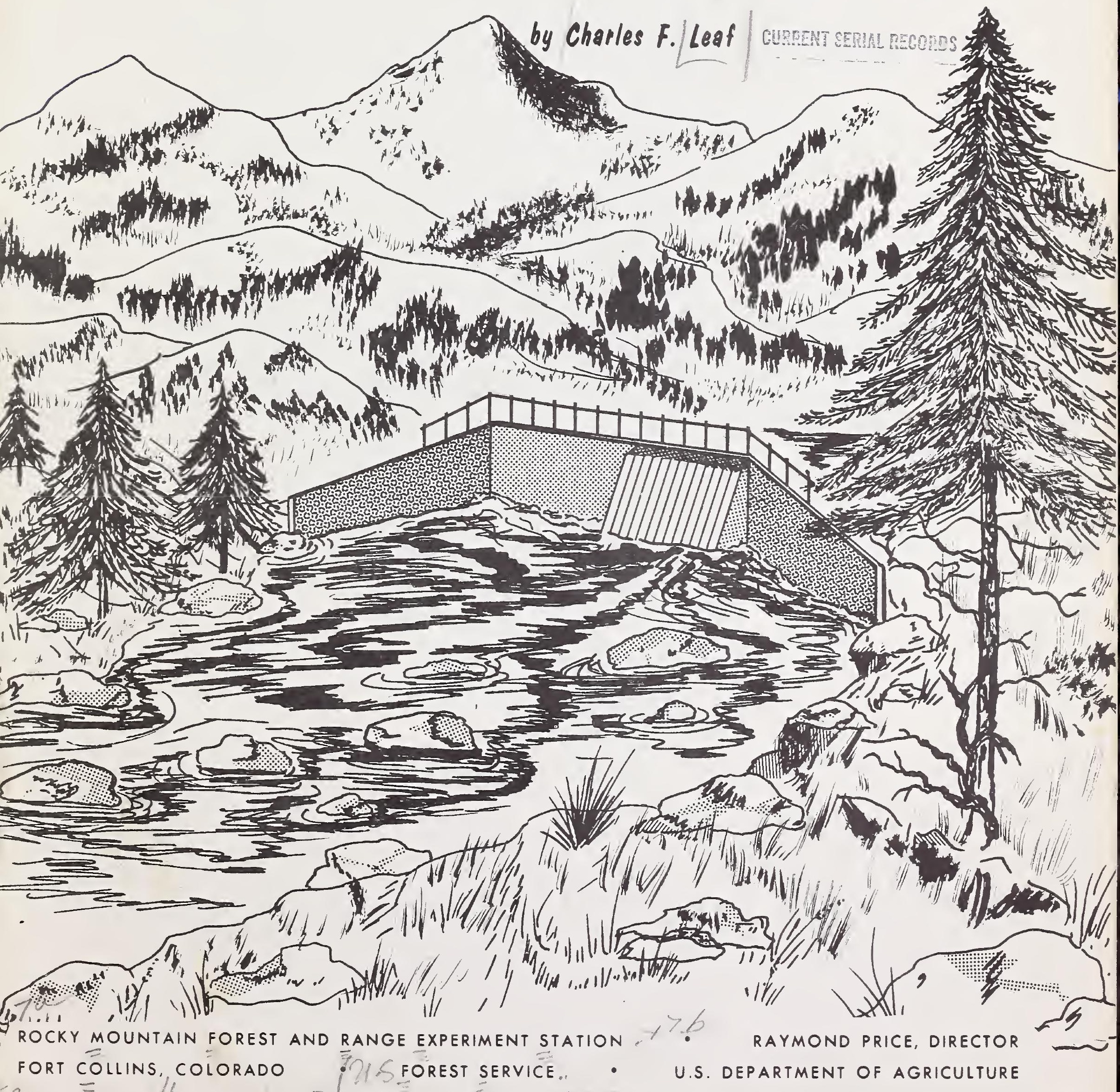


. 
SEDIMENT YIELDS FROM HIGH MOUNTAIN WATERSHEDS, CENTRAL COLORADO

\author{
2 by \\ Charles F. Leaf, Associate Hydraulic Engineer \\ Rocky Mountain Forest and Range Experiment Station ${ }^{1}$
}

${ }^{1}$ Central headquarters maintained in cooperation with Colorado State University at Fort Collins. 
CONTENTS

Page

The experimental watersheds ............. 1

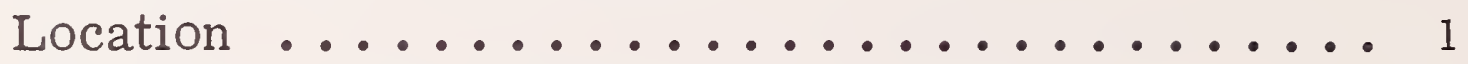

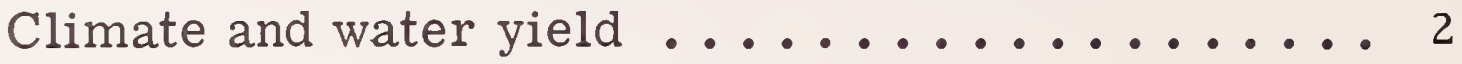

Geology, landforms, and soils ............ 2

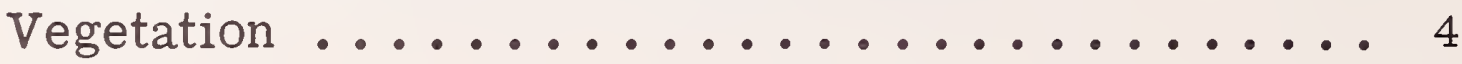

Sediment measurement, characteristics, and yields . . . 4

Records of annual sediment yields ......... 4

Properties of sediment deposits .......... 5

Trap efficiency ................... 6

Sediment yield in relation to peak streamflow .... 7

Sediment yield in relation to timber harvest ..... 8

Watershed geomorphology .............. 8

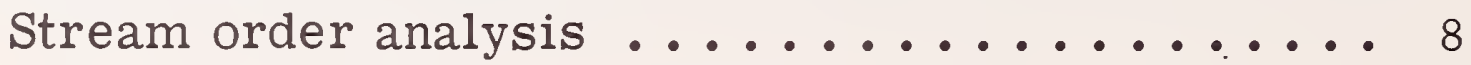

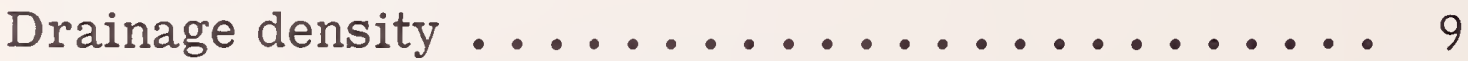

Constant of channel maintenance.......... 9

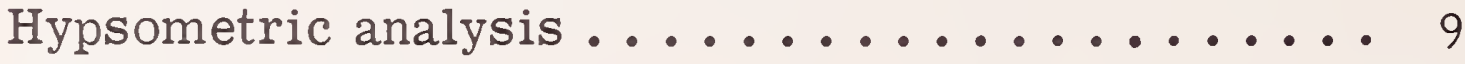

Channel profiles .................. 10

Estimating long-term sediment yields .......... 11

Sediment yields from small watersheds ........ 11

Calculated risks of annual events--design-

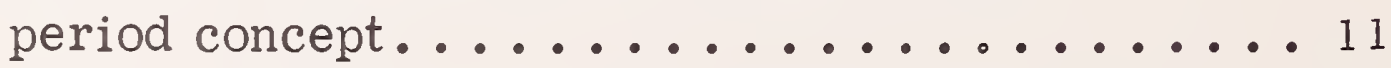

Use of design-period concept in estimating

annual sediment yields ............. 13

Summary and conclusions ................. 15

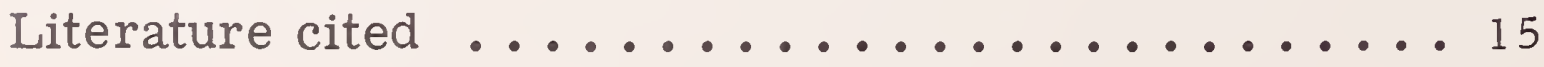




\title{
Sediment Yields from High Mountain \\ Watersheds, Central Colorado
}

\author{
Charles F. Leaf
}

With increased development of our water resources, we can expect a greater need for evaluating sediment yields from small mountainous watersheds. At present, insufficient data are available to make adequate estimates, especially in the high runoff areas of the central Rocky Mountains. In general, sediment yields from these areas are not high, but it is reasonable to expect that they are of sufficient magnitude to influence the design and operation of water projects.

In addition to development of existing water resources, efforts are currently underway to increase water yields from stable high-mountain watersheds by forest management. These activities require that extensive road systems be constructed. Information is needed on the effects of roads and forest-cover changes on sediment yields.

This paper discusses sediment yields from two undisturbed watersheds and one watershed from which one-half of the merchantable timber was removed by careful timber harvesting. The necessary logging roads on the harvested watershed were planned and built to minimize erosion. Selected geomorphic characteristics of the watersheds are evaluated. Magnitude-frequency relationships are developed for estimating long-term sediment yields by the "design period" approach.

The Experimental Watersheds

\section{Location}

The three watersheds are part of the Fraser Experimental Forest, which lies 65 miles west of Denver, Colorado (fig. 1). They are tributary watersheds of St. Louis Creek,

\footnotetext{
Figure 1.--Location map for Fraser Experimental Forest.
}

which in turn flows into the Fraser River. Dominant vegetation is lodgepole pine and spruce-fir forests typical of the central Rocky Mountains.

Their areas are:

\begin{tabular}{lc} 
Fool Creek & Acres \\
\hline Deadhorse Creek & 667 \\
Lexen Creek & 306
\end{tabular}

Deadhorse and Lexen Creeks are paired watersheds (fig. 2) on the west side of the Experimental Forest. Fool Creek (fig. 3) is situated on the east side of the Forest.

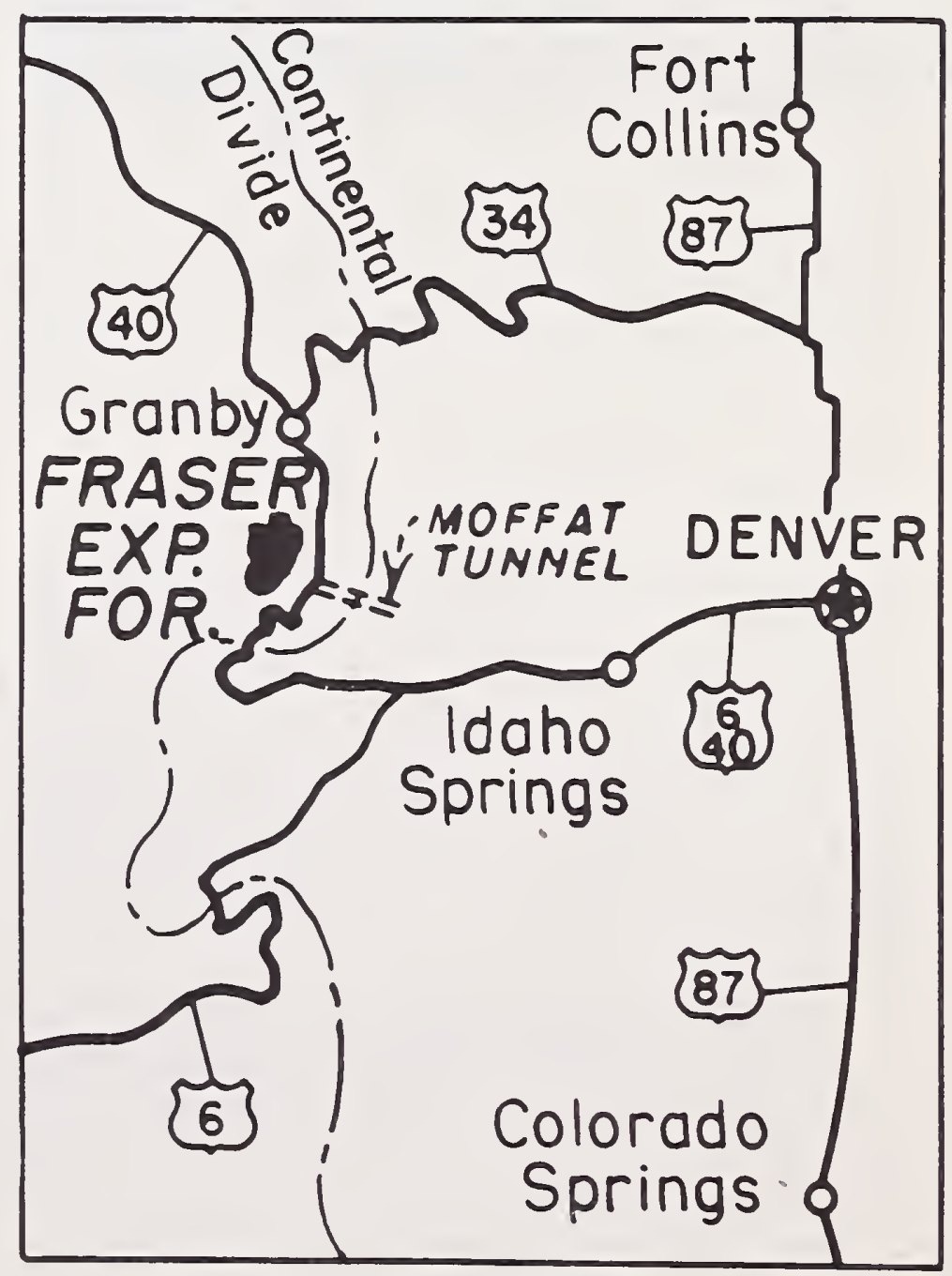


watersheds are both steeper than Fool Creek, with average slopes of approximately 36 and 39 percent, respectively. The average slope of Fool Creek is approximately 26 percent.

Soils are not easily eroded in the Fraser area. In general, the parent material of the soils on the watersheds was derived from gneiss and schist rocks (Retzer 1962). ${ }^{2}$ Typical soils contain angular gravel and stone and very little silt and clay. The soils are very permeable, and are capatle of storing considerable water during snowmelt. The mineral soil is normally covered with a dense litter composed of needles, rotting wood, and moss.

Near the top of Deadhorse and Lexen watersheds are soils which have developed in material weathered from sandstones. The soils are shallow over sandstone bedrock. They have a large amount of stone in their profile, and have fine sand or sand textures. The soils include a high percentage of rock outcrops.

2 Nomes and dates in parentheses refer to Literature Cited, p. 15.

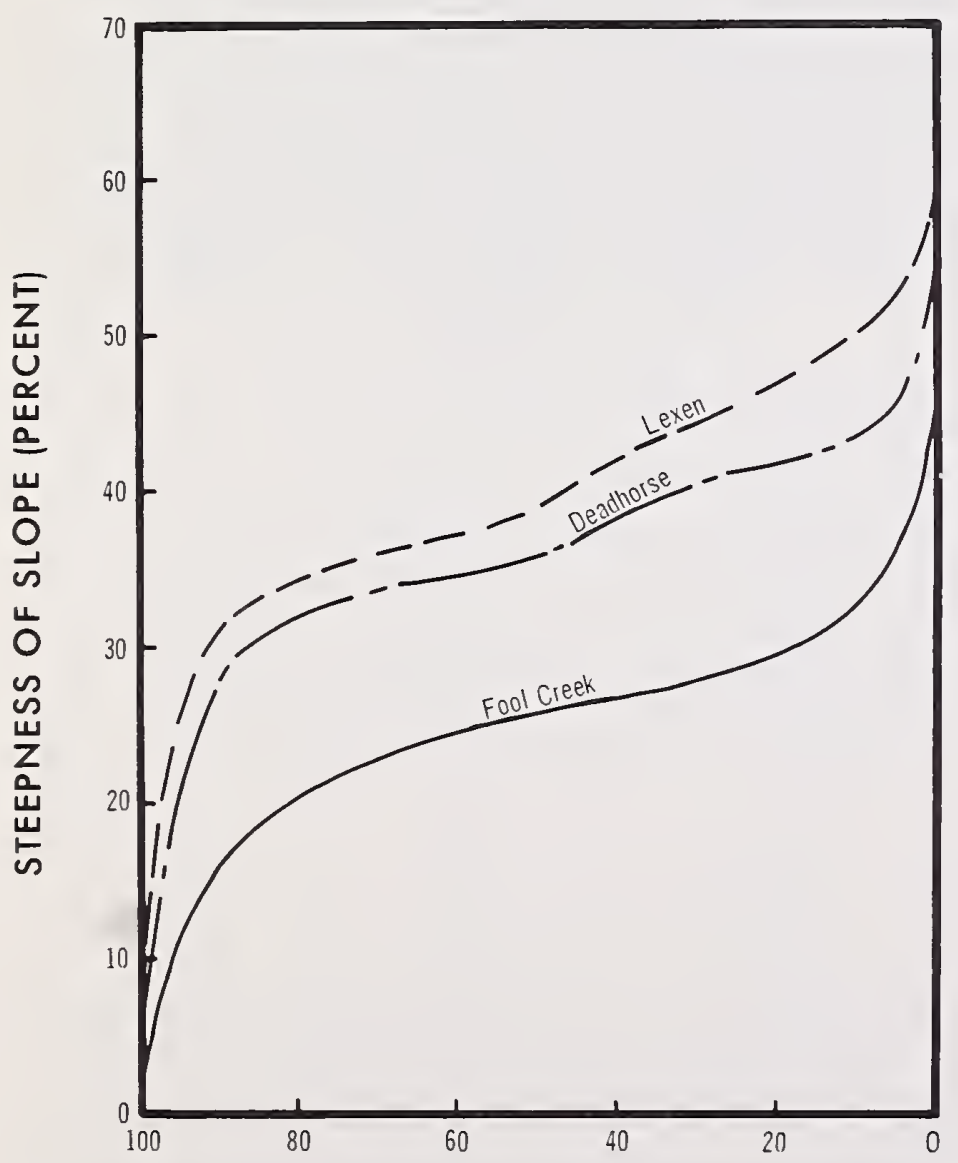

AREA GREATER THAN INDICATED SLOPE (PERCENT)

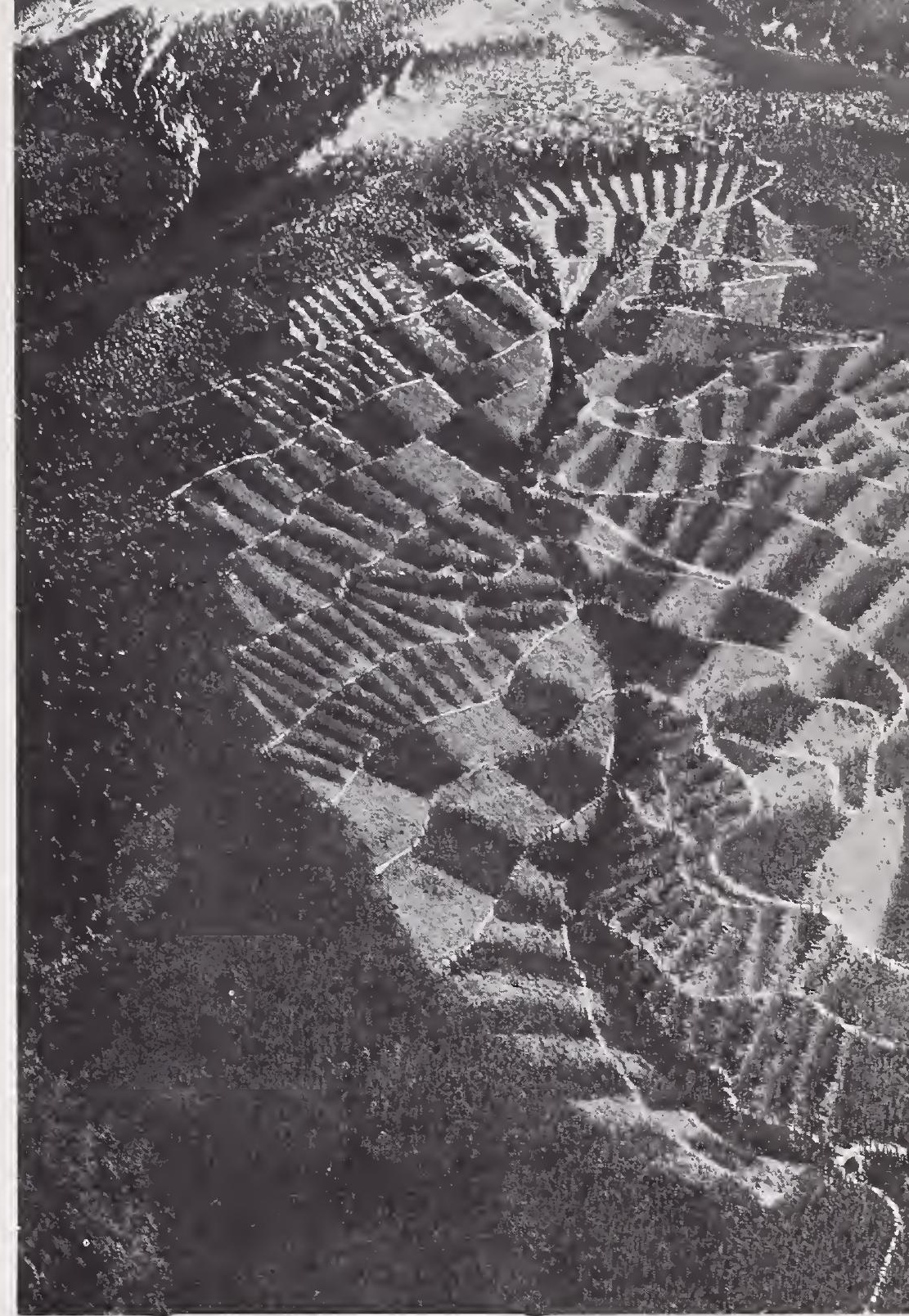

Figure 3.--Timber cutting pattern and road system on Fool Creek experimental watershed. Annual sediment accromulation is measured in the debris basin at the lower right-hand comer of photograph.

Alluvial soils occur along the main streams of all three watersheds. The parent material is a mixture of glacial till, glacial outwash, and recent valley fill. Three to four inches of litter covers the soil. The water table is generally near the surface, but dry spots occur locally on the higher areas of the glacial till deposits. There is little or no surface erosion, although there is some minor cutting along streambanks. Included on each watershed are bogs that owe their origin to seeps and springs which emerge on the slopes. Soils in these bogs are highly organic. The surface material consists of a mixture of wood, roots,

Figure 4.--Area-slope curves for Fool, Deadhorse, and Lexen watersheds. 
willow leaves, needles, and decomposed remains of various grasses. Under this organic material are layers of silt and clay with a high proportion of gravel and stones. Because of the vegetation and litter produced, it appears that these bogs serve well to retard excessive runoff and decrease channel erosion.

\section{Vegetation}

Alpine vegetation, found at the top of all three watersheds, is composed primarily of grasses and sedges which form meadow and tundra types. Clumps of shrubby willows are interspersed, usually on moist sites. There are large areas of bare rock. Soil-covered dry and exposed slopes support only cushion plant stands.

Between alpine and true forest there is usually a transition zone of stunted trees. Below this is the true forest composed of Engelmann spruce, subalpine fir, and lodgepole pine. Pine is more abundant at lower elevations and on south-facing slopes. There are small, scattered patches of quaking aspen. The forest floor is covered with deep litter. The most abundant minor vegetation is grouse whortleberry. Young trees and buffaloberry form an understory. More complete accounts of the vegetation can be found in Retzer (1962).

\section{Sediment Measurement, Characteristics, and Yields}

Records of Annual

Sediment Yields

The period of record from each watershed is as follows:

$\begin{array}{ll}\text { Fool Creek } & 1952-65 \\ \text { Deadhorse Creek } & 1955-65 \\ \text { Lexen Creek } & 1956-65\end{array}$

Sediment yields in cubic feet per square mile $\left(\mathrm{ft}^{3} / \mathrm{mi}^{2}\right)$, and annual instantaneous peak discharges in cubic feet per second per square mile (c.S.m.), are summarized for each watershed (table 1). The sediment yields are

Table 1.--Annual sediment yield and peak discharge from Fool, Deadhorse, and Lexen watersheds for period of record, $1952-65$

\begin{tabular}{|c|c|c|c|c|c|c|}
\hline \multirow{2}{*}{ Year } & \multicolumn{3}{|c|}{ Sediment yield } & \multicolumn{3}{|c|}{ Annual peak streamflow } \\
\hline & Fool Creek & Deadhorse & Lexen & Fool Creek & Deadhorse & Lexen \\
\hline & -- & $\mathrm{Ft} .3 / \mathrm{mi}^{2} 2$ & & -- & $-c_{0} s_{0} m_{0}-$ & -- \\
\hline 1952 & $\underline{1} / 1,408$ & -- & -- & 21.7 & -- & -- \\
\hline 1953 & 703 & -- & -- & 14.1 & -- & -- \\
\hline 1954 & $(2 / 3 /)$ & -- & -- & 2.2 & -- & - \\
\hline 1955 & $(\underline{\overline{2}} / \underline{\overline{3}} /)$ & 131 & -- & 6.1 & 3.8 & -- \\
\hline 1956 & $\underline{3 /} 1,150$ & 544 & 226 & 17.1 & 9.8 & 13.0 \\
\hline 1957 & 2,200 & 718 & 393 & 21.4 & 13.1 & 22.5 \\
\hline 1958 & 1,344 & 266 & 468 & 16.1 & 11.4 & 18.0 \\
\hline 1959 & 270 & 157 & 83 & 13.4 & 7.5 & 13.0 \\
\hline 1960 & 436 & 157 & 80 & 14.7 & 8.2 & 11.9 \\
\hline 1961 & 192 & 32 & 13 & 7.8 & 3.7 & 6.7 \\
\hline 1962 & 512 & 403 & 197 & 12.5 & 9.2 & 12.3 \\
\hline 1963 & $(2 /)$ & 29 & 8 & 4.6 & 2.4 & 2.2 \\
\hline 1964 & $(\overline{2} /)$ & 47 & 67 & 8.8 & 5.1 & 7.1 \\
\hline 1965 & $\overline{779}$ & 223 & 130 & 17.4 & 9.2 & 12.5 \\
\hline
\end{tabular}

1/ Road construction on Fool Creek.

$\overline{2} /$ Negligible accumulation.

$\overline{3} /$ Timber harvest on Fool Creek. 
Figure 5.--Fool Creek debris basin just downstream from San Dimas flume. The capacity of this pond is approximately one-fourth acrefoot.

based upon gross volumes of mineral and organic material as determined by annual surveys of debris basins. Survey points were located on 3- to 5-foot grids with elevations measured to the nearest 0.01 foot. The basins were drained before each survey was made. Typical debris basins are shown in figures 5 and 6.

\section{Properties of Sediment Deposits}

Except for flow conditions, the entrainment, transportation, and subsequent deposition of a sediment is largely dependent on the properties of the sediment itself. A useful and precise description of the more pertinent properties of a sediment can be obtained by means of a gradation or frequency distribution curve. Such a curve provides a means for grouping the sediment into different size classes and grades.

Figure 7 shows average grain-size distribution curves for accumulated sediment from the three debris basins. The grading curves were quantitatively evaluated by computing coefficients of uniformity $(\mathrm{Cu})$ and curvature of gradation curves (Cc) according to Hazen's criteria (U.S. Bur. Reclam. 1960).

The measure of size range is called the coefficient of uniformity $(\mathrm{Cu})$, which is the ratio of the 60-percent-finer-than size $\left(D_{60}\right)$ to the 10-percent-finer-than size $\left(D_{10}\right)$. The shape of the grain-size curve is given by the coefficient of curvature (Cc), which is the ratio of the square of the 30-percent-finerthan size $\left(\mathrm{D}_{30}\right)^{2}$ to the product of $\left(\mathrm{D}_{60}\right)$ and $\left(\mathrm{D}_{10}\right)$.

Figure 6.--Deadhorse weir. The rectangular debris basin behind the weir has a surface area of 408 square feet. A similar installation with a surface area of 200 square feet was constructed on Lexen watershed.

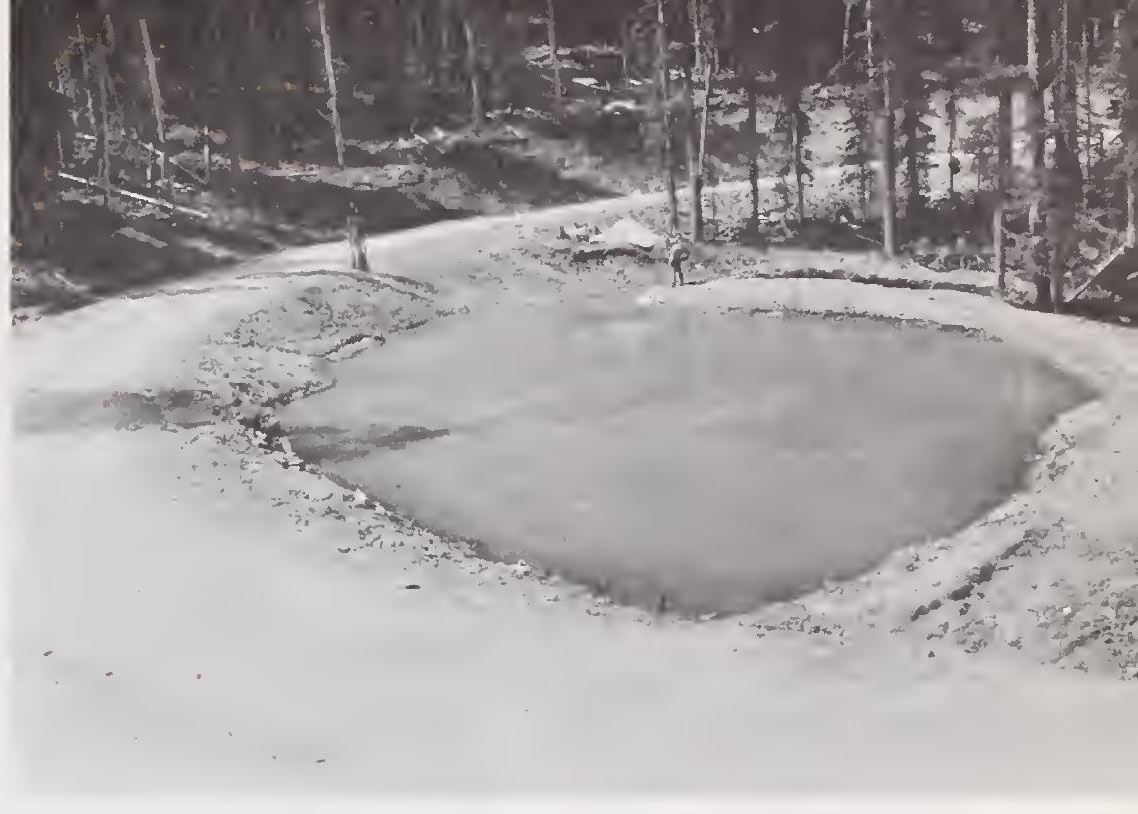

The coefficients were used to classify the samples according to the Unified Soil Classification System (U.S. Bur. Reclam. 1960), which provides for precise delineation of soil groups by laboratory analyses. There are three distinct sediment groups (fig. 7), including:

1. Well-graded gravel with little or no fines,

2. Poorly graded sand with little or no fines, and,

3. Silty or fine sand.

The samples of finer sand were taken from the Fool Creek debris basin; its presence in appreciable quantities is most likely the result of road construction on the watershed.

One of the main interests of those working with deposited sediments involves predicting the depletion of reservoir storage. Prior to construction of a reservoir, the sediment transported by a river or stream is usually measured on the basis of weight per unit time. To obtain an estimate of the expected

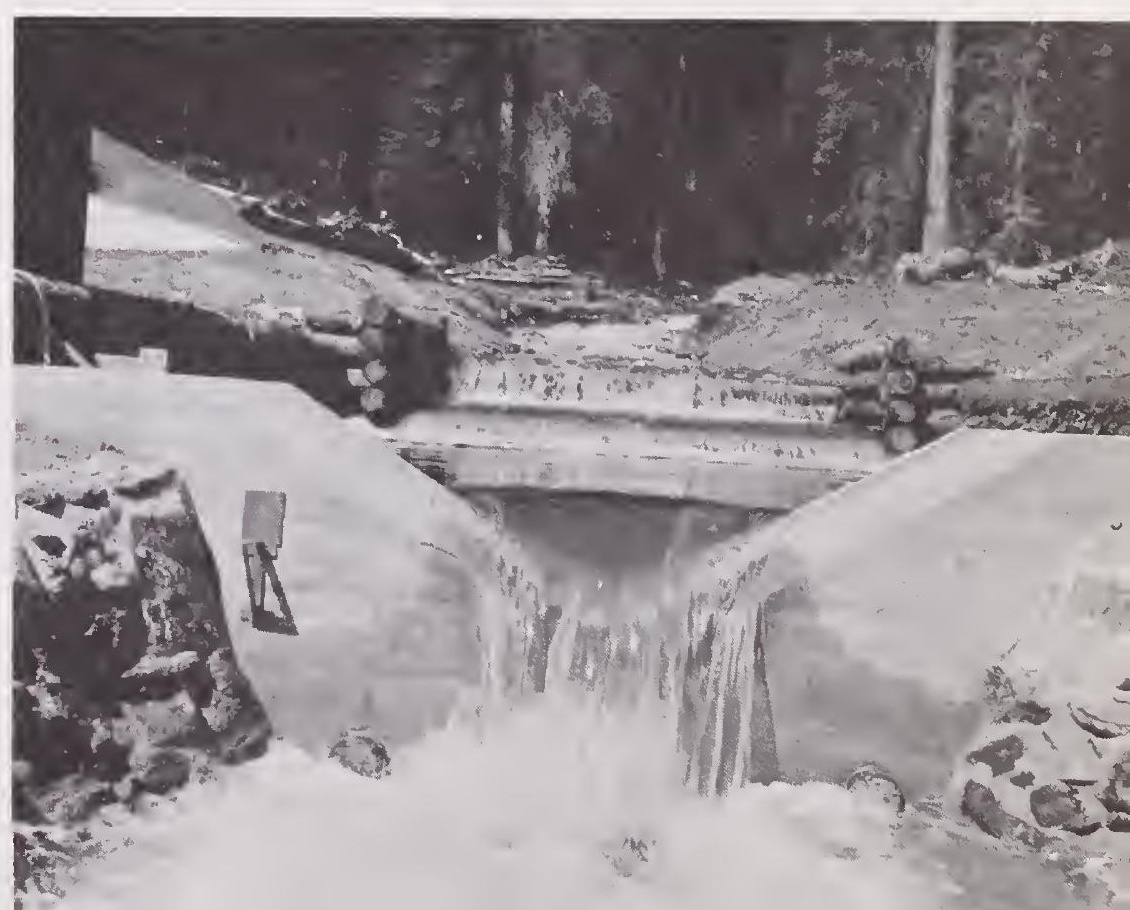


Figure 7.--

Typical grading curves for deposited sediment from Fool, Deadhorse, and Lexen debris basins.
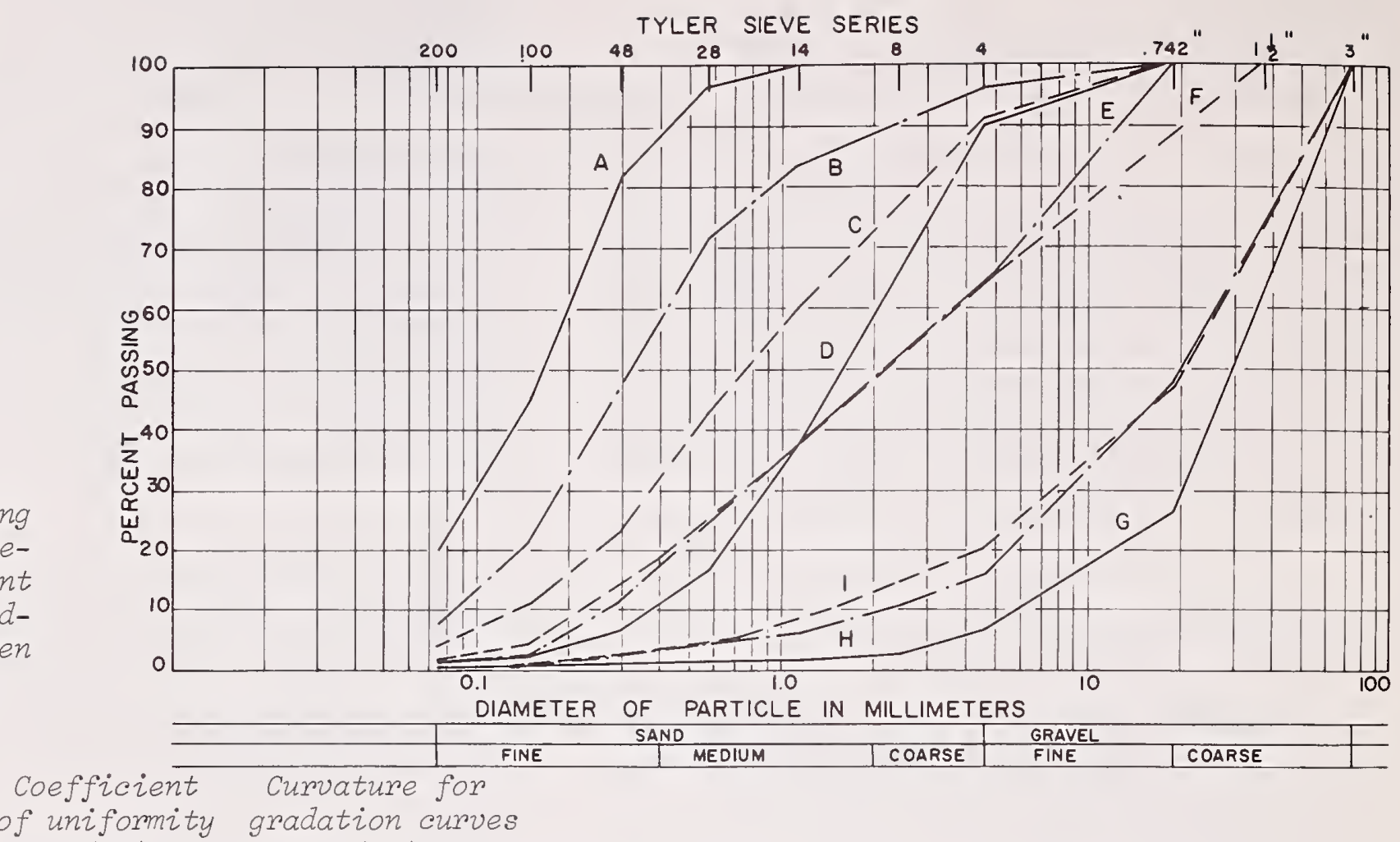

Curve Watershed

of uniformity gradation curves

$\begin{array}{llrc}\text { A } & \text { Fool Creek } & 3.3 & 0.88 \\ B & \text { Deadhorse } & 4.8 & .96 \\ C & \text { Lexen } & 7.7 & .83 \\ D & \text { Fool Creek } & 5.5 & 1.07 \\ \text { E Deadhorse } & 12.9 & .54 \\ \text { F Lexen } & 16.5 & .70 \\ G & \text { Fool Creek } & 6.2 & 1.9 \\ H & \text { Deadhorse } & 11.2 & 1.3 \\ I & \text { Lexen } & 18.2 & 1.6\end{array}$

volume to be occupied by the deposited sediment, it is necessary to have its specific weight. Experience has shown that the specific weight of deposits varies with mechanical composition, environment, and time. The variation of specific weight (dry unit weight) with sediment class and particle size is summarized for Fool, Deadhorse, and Lexen debris basins (table 2). The deposits were laid down for a period of 2 years prior to sampling.

\section{Trap Efficiency}

Brune (1953) has pointed out that the trap efficiency of a reservoir or debris basin depends on a number of factors, such as ratio between the storage capacity and inflow, age of the reservoir, shape of the reservoir basin, type of outlets and method of operations, the size grading of the sediment, and behavior of the finer sediment fractions under various conditions. The trap efficiency of reservoirs is affected by the same factors, regardless of reservoir size.

Table 2.--Variation of specific weight with sediment class and particle size

\begin{tabular}{|c|c|c|c|}
\hline $\begin{array}{c}\text { Debris basin } \\
\text { and } \\
\text { class of } \\
\text { sediment }\end{array}$ & $\begin{array}{l}\text { Median } \\
\text { diameter }\end{array}$ & $\begin{array}{l}\text { Particles } \\
\text { greater } \\
\text { than } \\
1 \mathrm{~mm} \text {. }\end{array}$ & $\begin{array}{l}\text { Specific } \\
\text { weight }\end{array}$ \\
\hline & $\mathrm{mm}$. & Pct. & $\mathrm{Lb} . / \mathrm{ft} .{ }^{3}$ \\
\hline \multicolumn{4}{|l|}{ Fool Creek: } \\
\hline Gravel & 30.00 & 99.0 & - \\
\hline Sand & 2.69 & 78.5 & 110.1 \\
\hline Sand & 2.00 & 70.0 & 127.8 \\
\hline Sand & 1.63 & 69.0 & 106.8 \\
\hline Sand & 1.30 & 63.0 & 118.6 \\
\hline Sand & .29 & 3.0 & 78.8 \\
\hline Fine sand & .13 & 0 & 45.7 \\
\hline Fine sand & .12 & 0 & 60.6 \\
\hline \multicolumn{4}{|l|}{ Deadhorse Creek: } \\
\hline Gravel & 21.20 & 93.5 & 134.9 \\
\hline Fine gravel & 4.60 & 76.5 & 111.3 \\
\hline Fine gravel & 1.85 & 64.5 & 111.3 \\
\hline Sand & 1.41 & 57.8 & 105.6 \\
\hline Sand & .35 & 20.0 & 79.0 \\
\hline Sand & .33 & 18.0 & 79.0 \\
\hline \multicolumn{4}{|l|}{ Lexen Creek: } \\
\hline Gravel & 20.70 & 93.4 & 131.5 \\
\hline Gravel & 2.55 & 69.0 & 84.0 \\
\hline Gravel & 2.25 & 66.0 & 84.0 \\
\hline Sand & .89 & 47.0 & 77.4 \\
\hline Sand & .72 & 41.2 & 77.4 \\
\hline
\end{tabular}


Virtually all information available on trap efficiency has been based on data from larger storage reservoirs in lowland areas. Consequently, relatively little is known about the efficiencies of smaller water-retarding structures in mountainous regions.

Data presented by Moore et al. (1960) from the debris basin program in the Los Angeles area indicate that in nearly all cases, trap efficiencies approach 100 percent, for coarsegrained debris, even during periods when both inflow and outflow take place.

The debris from Fool, Deadhorse, and Lexen debris basins is likewise coarse (table $2)$; it is believed that the basins trap virtually all of the eroded material. Suspended sediment samples taken from the outflow of the debris basins during peak streamflow in 1964 and 1965 showed maximum concentrations of less than 5 p.p.m. Peak flows during the 1965 snowmelt season were the highest since 1957.

\section{Sediment Yield}

in Relation to Peak Streamflow

The total amount of sediment yielded from a stream depends upon the physical characteristics of the watershed and climatic factors. Furthermore, it is generally assumed to be derived from two erosional processes-sheet erosion and channel erosion. The total sediment load for a stream, then, is recognized to be composed of fine material or wash load derived from sheet erosion, and bedmaterial load derived from channel erosion.

The quantity of wash load in a stream at any time depends on the rate at which fine particles become available from the watershed, and not on the ability of the flow to transport them. It is a function of such factors as intensity, quantity, and distribution of rainfall, soil type, vegetation cover, relief, and channel density.

Bed-material load in a stream is mainly derived from gully erosion, streambank erosion, and channel degradation. The quantity of bed-material load in a stream at any time depends on the hydraulic characteristics of the flow.
Where a major part of the total load is composed of material which moves as bedload, a good relationship is expected between sediment yield and discharge. Concentration of wash load, however, is more directly related to supply rather than discharge. Hence, the climatic and physical factors affecting its transport have a greater influence than does the discharge. Relationships between annual instantaneous peak discharge and annual accumulated debris for Fool, Deadhorse, and Lexen watersheds (fig. 8) show a good correlation between sediment yield and annual peak flow. All correlation coefficients tested were significant at the 95-percent level of confidence. The linear relationships (fig. 8) accounted for an average of 83 percent of the variance.

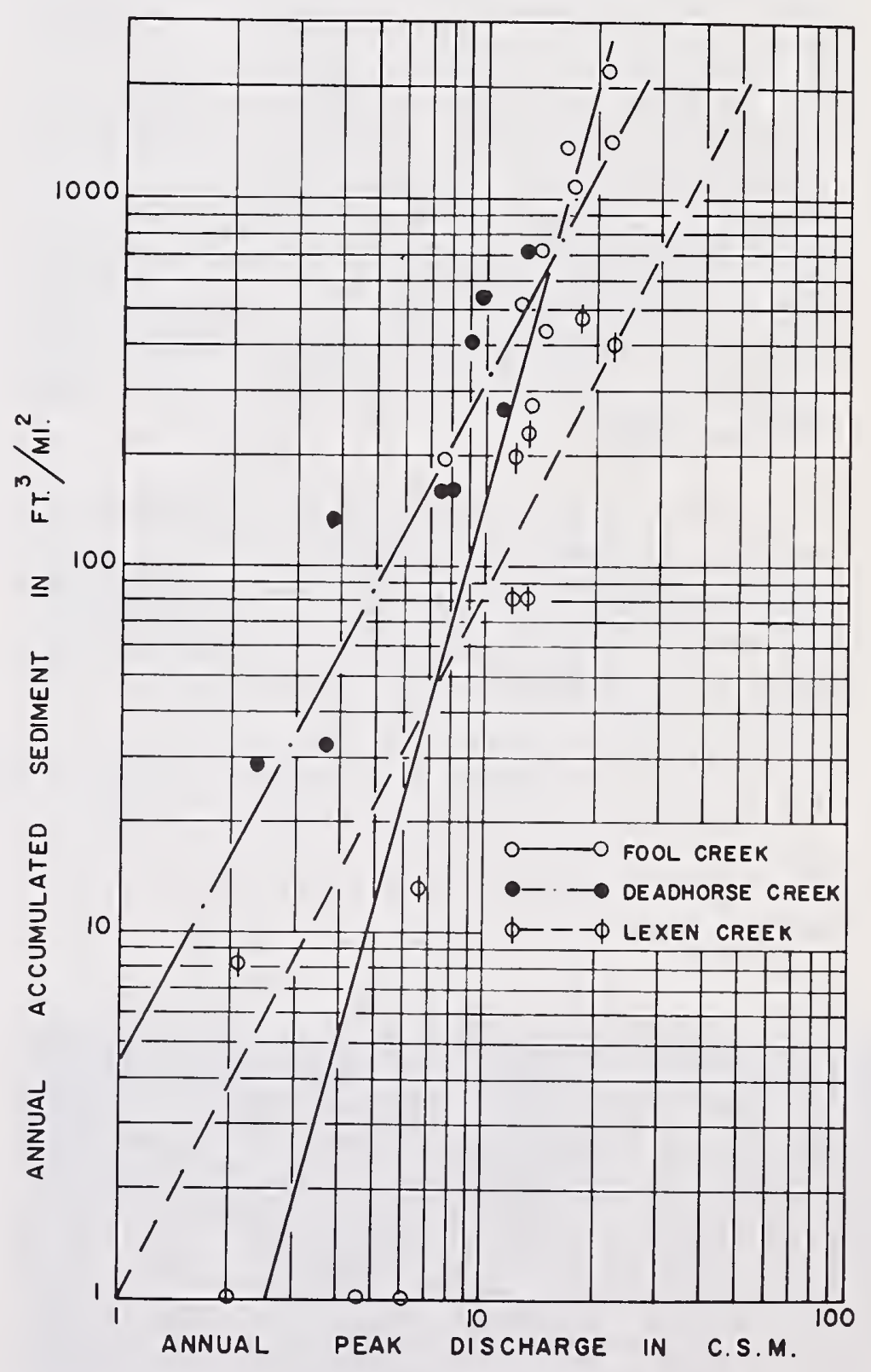

Figure 8.--Relationships between sediment yield and peak discharge for Fool, Deadhorse, and Lexen watersheds. 
Sediment yields from these watersheds are also highly correlated with total annual flows. The relationships indicate that a major portion of the total sediment load is composed of bed material derived from streambank erosion and channel degradation. The low suspendedsediment concentrations observed during peak streamflow also indicate that virtually all the sediment yield is derived from channel erosion.

Sediment Yield

In Relation To Timber Harvest

The effect of timber harvest on sediment yields can only be indirectly evaluated because there is no pretreatment record. Sediment yields from the logged watershed were relatively large during the years immediately following treatment. Yields in subsequent years have been considerably less even though the average annual increase in streamflow has been about 25 percent since cutting (Martinelli 1964). A statistical comparison showed no difference in mean annual sediment yields from the three watersheds for the period 1956 through 1963.

Field inspection of the Fool Creek road system in 1964 has indicated that no gross damage from erosion has occurred since treatment. Figure 9 shows examples of the most extreme gullying activity observed.

\section{Watershed Geomorphology}

Because sediment yields from the three watersheds are largely the result of the fluvial geomorphic cycle, a consideration of various geomorphic properties relating to sediment yield should logically give a better understanding of the nature of these yields.

Important geomorphic properties which influence sediment yields are:

1. Stream orders,

2. Drainage density and related parameters,

3. Amount of relief or stage in geomorphic cycle, and

4. Channel characteristics.

\section{Stream Order Analysis}

Generally, the first step in the geomorphic analysis of a given basin begins with stream order designation, following a system from Horton (1945). Horton's law of stream numbers states that the numbers of stream segments of each order form an inverse geometric sequence with order number. A regression of logarithm of number of streams of each order (ordinate) on stream order (abscissa) generally yields a straight-line plot. The antilogarithm of the slope of the line is Horton's bifurcation ratio $r_{b}$. Such curves for Fool, Deadhorse, and Lexen watersheds are shown in figure 10 . The bifurcation ratios

\footnotetext{
Figure 9.--Exomples of most severe erosion observed on Fool Creek watershed, Fraser Experimental Forest.
}
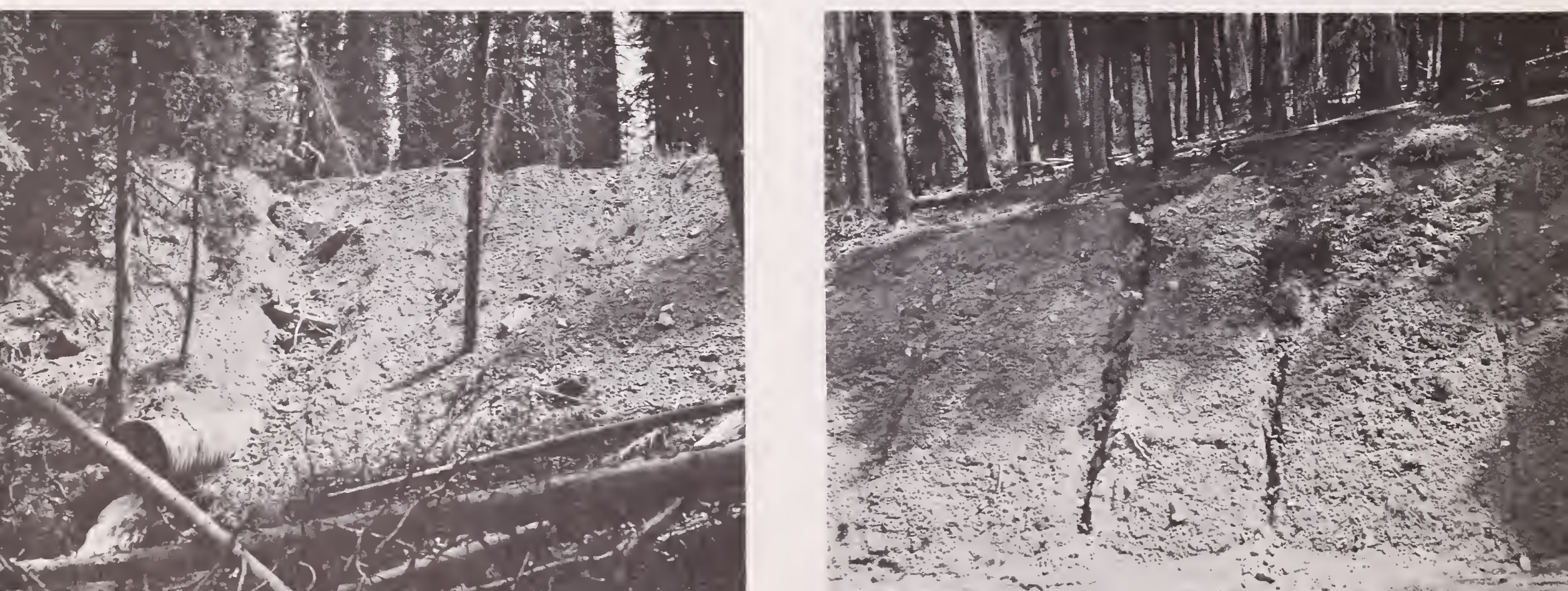
Figure 10.--Regression of number of streams on stream order for Fool, Deadhorse, and Lexen watersheds.

for the three watersheds have the values 4.0 , 3.2 , and 3.0 , respectively.

Strahler (1957) indicates that the bifurcation ratio is a very stable number, and shows a small range of variation for all regions regardless of environment. Furthermore, the ratios of second-order to third-order streams range from 2.8 to 4.9 . The ratios computed from figure 10 are in good agreement with these criteria.

\section{Drainage Density}

Horton defines drainage density as the sum of the channel lengths of all orders divided by basin area. This yields a number with the dimension of inverse of length. Drainage density is of primary importance in landform scale analysis. It is reasonable to expect that sediment yield follows a close positive relationship with drainage density. Strahler has indicated that low drainage densities in the order of 3 to 8 miles per square mile are associated with erosion-resistant basins, whereas drainage densities on the order of 200 to 900 miles per square mile indicate very unstable basins with high sediment production. The values computed for Fool, Deadhorse, and Lexen watersheds are in line with these figures. They are respectively: $4.8,8.3$, and 6.5 miles per square mile.

\section{Constant of Channel Maintenance}

The inverse of drainage density has been used by Schumm (1956) as a property termed "constant of channel maintenance." This constant gives an indication of the average area necessary to maintain one unit of channel length. A typical constant of channel maintenance for the Perth Amboy badlands is 8.7 square feet per foot length, whereas in the California San Gabriel Mountains, about 316 square feet of surface are required to maintain 1 foot of channel length (Schumm 1956). Constants of channel maintenance for Fool, Deadhorse, and Lexen watersheds are 1,070, 612 , and 765 square feet of surface per foot of channel length, respectively.

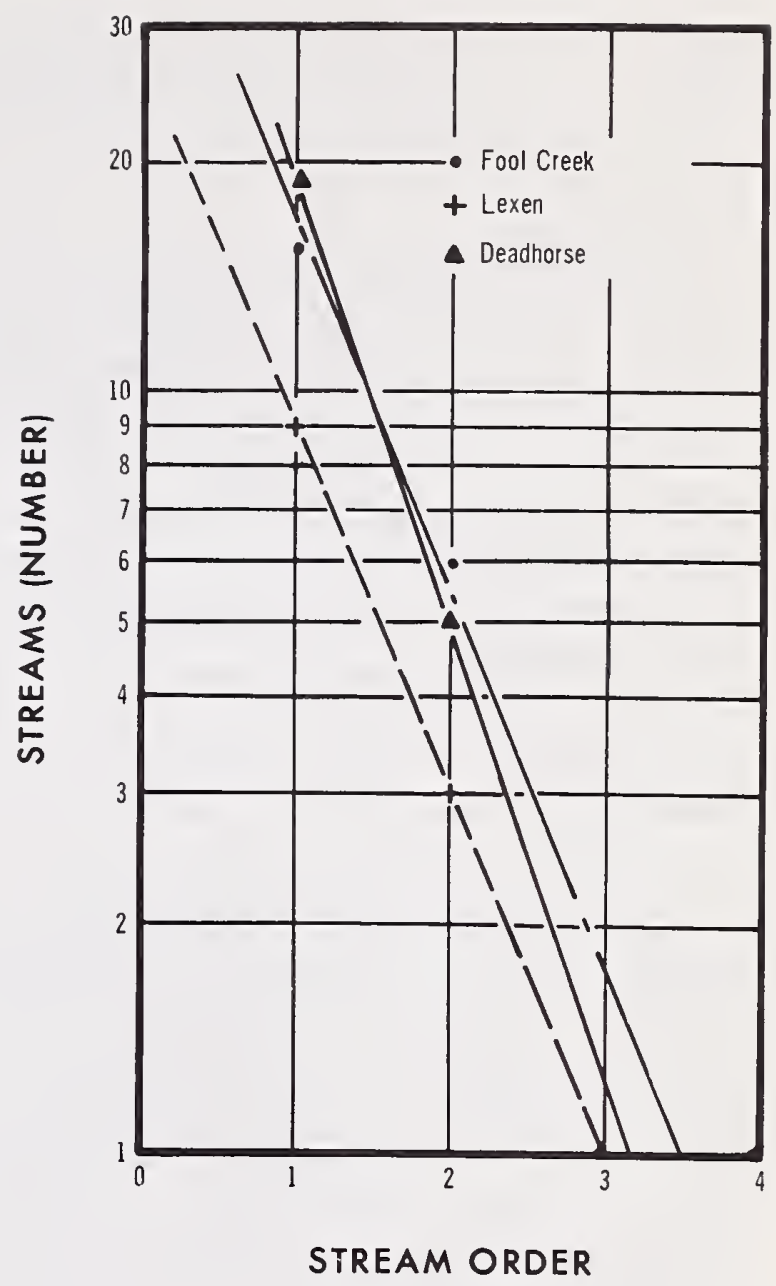

Hypsometric Analysis

Strahler has proposed hypsometric analysis that can be applied to a given drainage basin to determine how its mass is distributed from base to top. Two dimensionless variables are involved, relative height and relative area. Taking the drainage basin to be bounded by vertical sides and a horizontal base plane passing through the mouth, the relative height is the ratio of a given contour (h) to total basin height $(\mathrm{H})$. Relative area is the ratio of horizontal cross-sectional area (a) to entire basin area (A). The percentage hypsometric curve is a plot of the continuous function relating relative height to relative area. Strahler indicates that two stages seem to mark the evolution of drainage systems in a fluvial cycle:

1. An early inequilibrium stage, during which slope changes take place rapidly as drainage expands, and

2. An equilibrium stage, in which a stable hypsometric curve develops and persists as relief diminishes. 
A special monadnock phase may be recognized, but it is transitory and destruction of the monadnock is followed by restoration of the equilibrium form.

Dimensionless relations of horizontal cross-sectional area to elevation for Fool, Deadhorse, and Lexen watersheds are shown in figure 11. Also shown in figure 11 are the characteristic erosion cycle curves as given by Strahler. All three relationships closely approximate characteristic curves for the equilibrium or mature stage of geologic development.

\section{Channel Profiles}

An important geomorphic concept is that a stream rather early in the geomorphic cycle attains that slope or gradient which, under existing conditions of discharge and channel characteristics, is just sufficient for transportation of its load. Such a stream is said to be graded or at grade. A graded stream is not loaded to capacity; it may be either eroding or depositing. Erosion in one part of a stream channel and deposition in another part are as characteristic of a graded stream as of a nongraded one. Although a stream at grade has attained a unique gradient, it is not gradient alone that determines the graded condition. Other factors are involved, such as velocity, channel characteristics, and the nature of the material the stream has to transport. The graded condition does not imply either a high or low gradient. High-gradient streams can be in a graded condition as well as low-gradient streams.

The longitudinal profile of a graded stream is referred to as a profile of equilibrium. It is generally a smoothly concave-upward curve which decreases in slope gradually and systematically down-valley. The three study streams have this profile.

Figure 12 shows a comparison of the channel profiles of Fool, Deadhorse, and Lexen watersheds, in which the main stems are plotted to a distance of about 7,000 feet above the stream gages. The profiles plot as nearly parallel, straight lines on semilogarithmic paper, which indicates that the

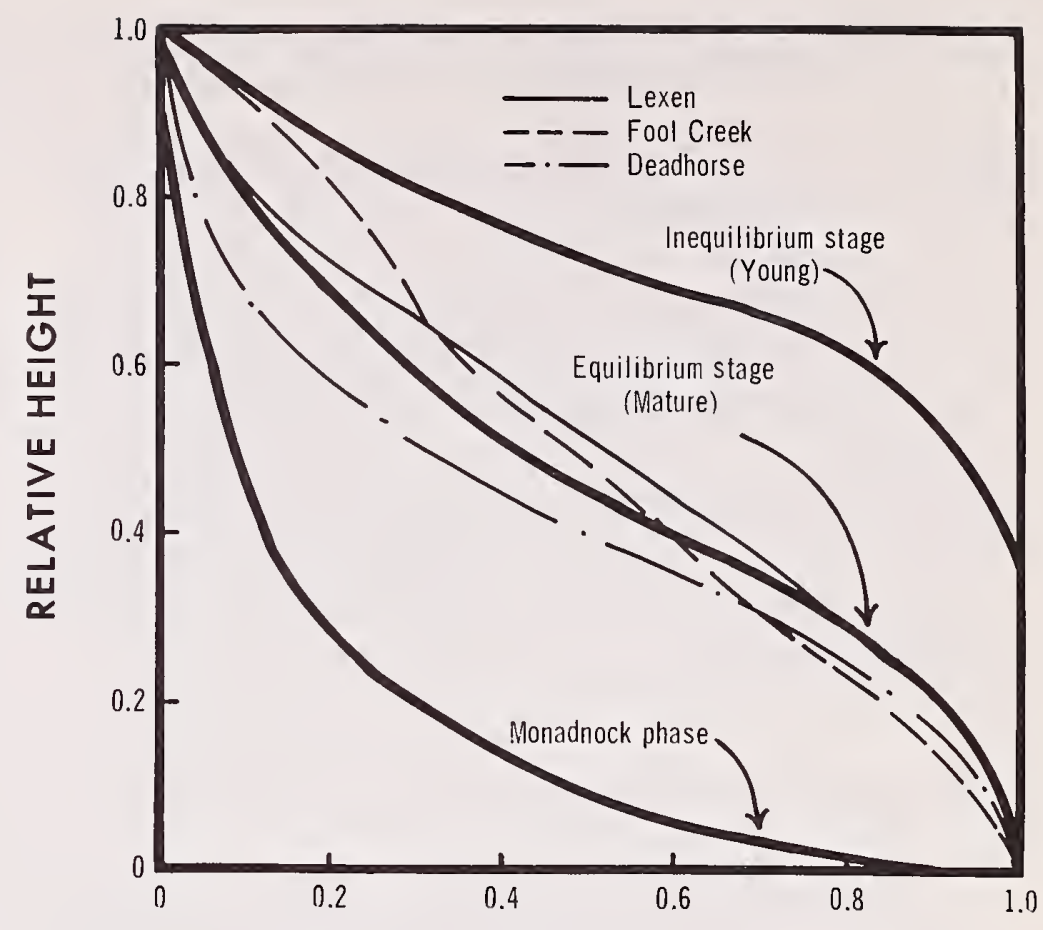

RELATIVE AREA

Figure 11.--Hypsometric curves for Fool, Deadhorse, and Lexen watersheds. Also, characteristic curves of erosion cycle(Strahler 1957).

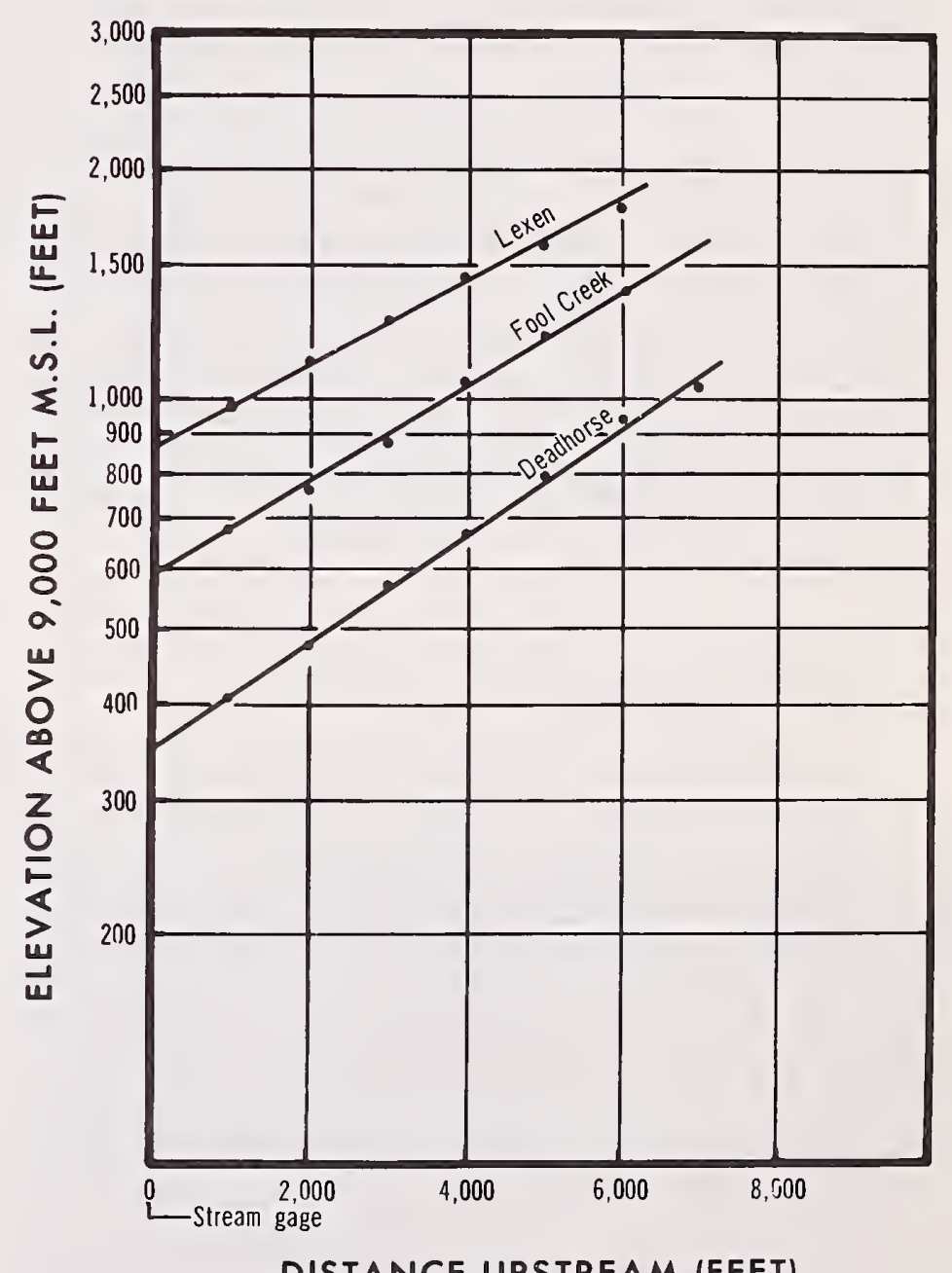

DISTANCE UPSTREAM (FEET)

Figure 12.--Comparison of channel profiles for Fool, Deadhorse, and Lexen watersheds (semiZogarithmic plot). 
streams have attained profiles of equilibrium and can be considered to be graded. The low unit sediment yields also indicate that the channels have attained profiles of equilibrium.

\section{Estimating Long-Term Sediment Yields}

Sediment Yields

from Small Watersheds

There is a need for sediment-yield data to define the capacity loss of water storage and diversion works on small mountain watersheds. Examples of such works are:

1. Forebay storage for power operation, and

2. Diversion storage for irrigation or municipal use.

The successful operation of such structures makes it desirable or even necessary in most cases to exclude as much of the sediment as possible. Hence, means for this exclusion must be provided for in their design. Many of these structures are located in headwater areas at high elevations or downstream from larger storage dams; the source of sediment is the natural pickup out of the main channel plus sediment inflow from intervening small drainages.

Sediment inflow from small mountainous watersheds, and the ability of the flows to move this load to the diversion point, may be quite significant during the design life of a given structure. As an example, figure 13 shows a sizable accumulation of sediment and debris behind a log jam on St. Louis Creek in the Fraser Experimental Forest. The jam is the result of logging operations in the area between 1910 and 1926 (Retzer 1962).

\section{Calculated Risks of Annual \\ Events--Design-Period Concept}

Many hydrologic structures are commonly designed to withstand a natural event with a selected "recurrence interval" (defined as the reciprocal of the probability of exceedence). An estimate of the recurrence interval of an event usually is obtained from a cumulative frequency curve. The recurrence interval as commonly derived from the cumulative frequency curve is an average or mean value, The actual intervals of time between exceedence of a given magnitude vary widely from the mean. The mean recurrence interval has considerable meaning as a representative value and as an aid to judgment. It has even more meaning if the dispersion of the individual intervals about the mean can be determined.

Riggs (1961) has shown that the probability of an n-year event not being exceeded in an $n$-year period is about 0.36. Additional information regarding more than one probability of exceedence during the design period is useful for the selection of alternatives which provide for the most efficient operation of a given structure. Riggs has proposed a method for computing additional probabilities by modifying the conventional frequency curve. This is accomplished by relating the recurrence interval of an event to the probability that the magnitude of the event will not be exceeded during any selected design period. The modifications are not confidence limits on the position of the frequency curve. They provide a more complete interpretation of the frequency curve as defined by the data. By considering various magnitudes and various design periods, a system of governing risks can be calculated which provides the engineer with more flexibility in selecting an appropriate design.

To illustrate the modification procedure, a relationship is derived between magnitude of an event $E$ and design period such that there is a 0.5 probability of not exceeding the event in the design period. Let $1-\underline{P}$ equal the probability of not exceeding $\underline{E}$ in 1 year, and let $\underline{n}$ equal the number of years. Then

$$
(1-P)^{n}=0.5
$$

Values of $P$ and corresponding recurrence intervals computed by the foregoing equation are summarized below for several design periods:

\begin{tabular}{|c|c|c|}
\hline Design period & Probability, P & $\begin{array}{l}\text { Recurrence } \\
\text { interval, } 1 / \mathrm{P}\end{array}$ \\
\hline 2 & 0.293 & 3.4 \\
\hline 3 & .206 & 4.9 \\
\hline 5 & .129 & 7.8 \\
\hline 10 & .067 & 14.9 \\
\hline 20 & .034 & 29.4 \\
\hline
\end{tabular}


Figure 13.--Sediment accrmulation behind log jom on St. Louis Creek, Fraser Experimental Forest.

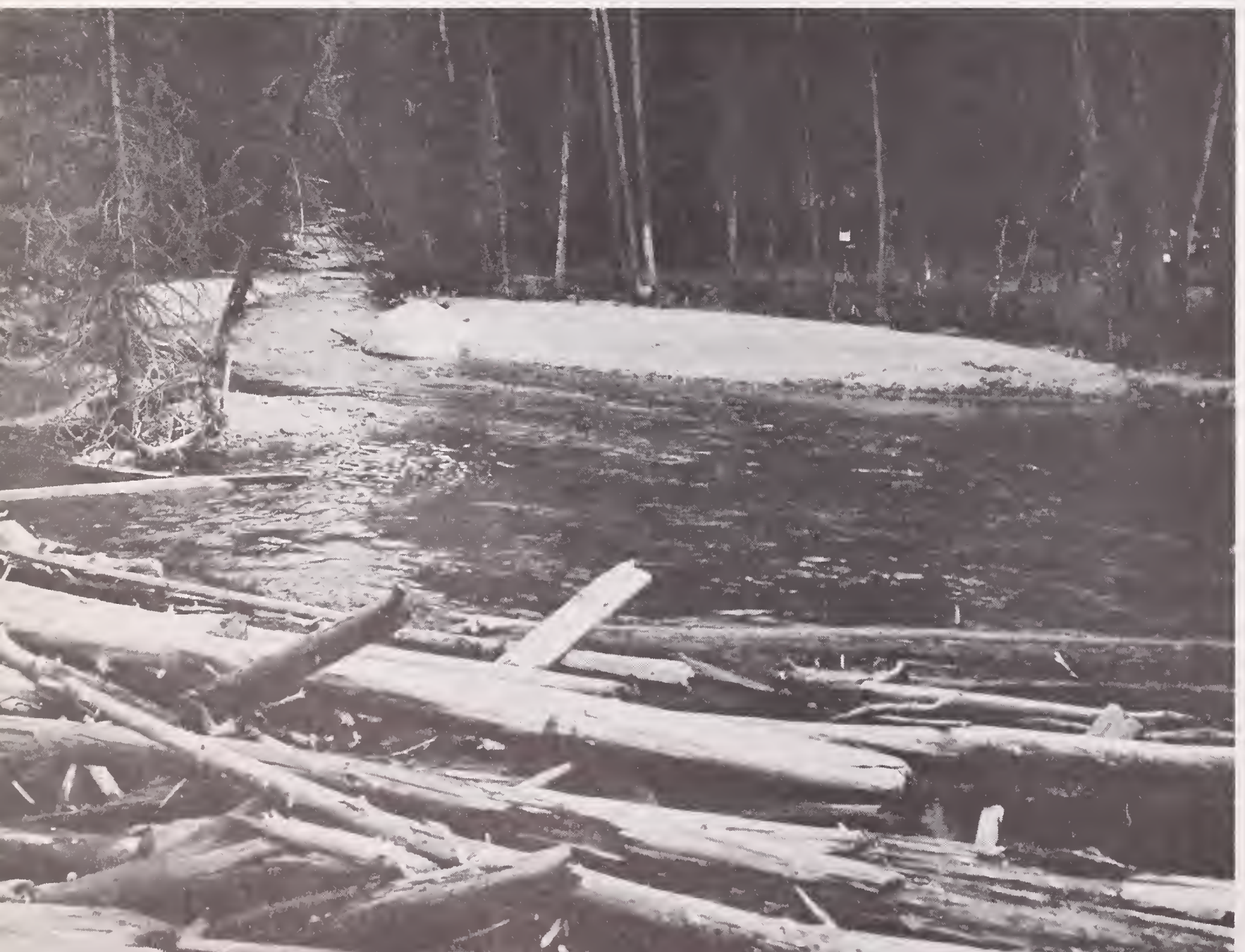


These results indicate that the 3.4-year event from the cumulative frequency curve is the one that has a 0.5 probability of not being exceeded in a single 2-year period. Likewise, the 29.4-year event from the frequency curve has a 50-50 chance of being exceeded during a design period of 20 years.

These results may be used to modify a frequency curve by plotting the magnitude of the 3.4-year recurrence interval event at the 2 -year design period, the 7.8- at the 5 , the 14.9 - at the 10, and so forth. Similar adjustments for different probabilities $P$ can be computed by substituting the desired probability instead of 0.5 in formula (1) and recomputing $\underline{\mathrm{P}}$ and recurrence interval.

The method is limited by the assumption that the magnitude-frequency relationship is exactly defined to large recurrence intervals. In actual practice, a curve based on a small sample must be used, hence the results are only as good as the data.

Use of Design-Period Concept in Estimating Annual Sediment Yields

Combined average annual sediment yields from Deadhorse and Lexen watersheds are plotted as a cumulative frequency curve in figure 14. The curve is based on the period
1956-65 as summarized for both watersheds in table 1. The vertical scale is logarithmic and shows average annual sediment yields in cubic feet per square mile $\left(\mathrm{ft}^{3} / \mathrm{mi}^{2}\right)$. The horizontal scale follows the normal probability law. It shows the recurrence interval in years when applied to the solid frequency curve. The horizontal scale also shows the design period in years when applied to the dashed lines. These dashed lines show mean annual accumulated sediment determined by the modification procedure discussed in the previous section of this paper.

Figure 14 clearly indicates that, no matter what design period is used, there is still an appreciable probability of experiencing a larger event in that period. This is often overlooked in interpreting the conventional frequency curve.

Despite the fact that the observed unit sediment yields from the two watersheds were quite small, figure 14 suggests that significant accumulations of sediment can be expected at a diversion point. For example, the 10-year recurrence interval accumulation is about 600 eubic feet per square mile. During a 10-year period, however, there is an even chance that the highest sediment yield will exceed 700 cubic feet, and a 30 percent chance that it will exceed 850 cubic feet per square mile.

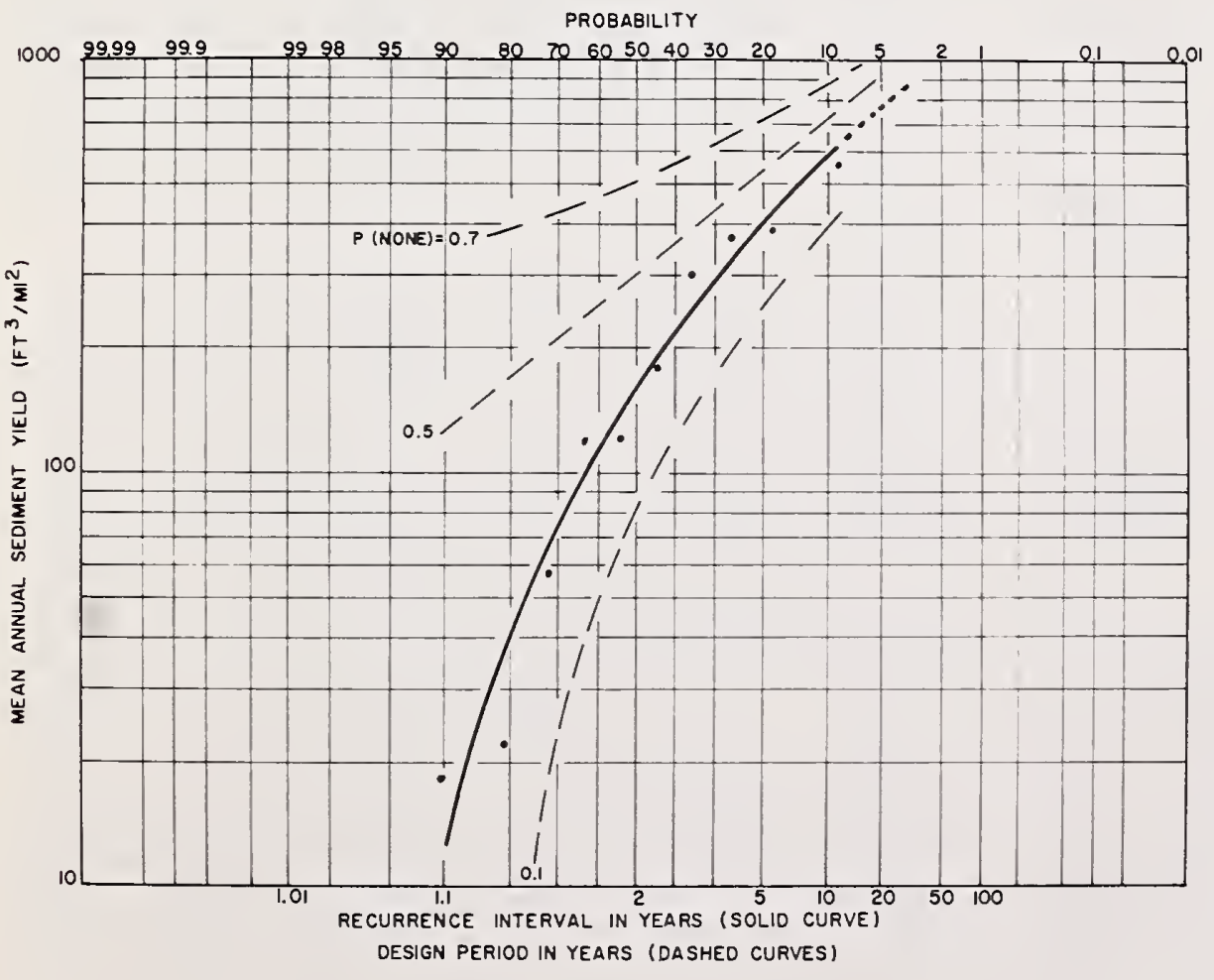

Figure 14.-Frequency and yiezd probability curves for mean annual accumulated sediment from Deadhorse and Lexen watersheds. 
Although the probability of experiencing no exceedences during the design period is generally of primary interest, it is sometimes desirable to know the probabilities associated with other outcomes. This is particularly true in the design of sediment detention or exclusion works, where designs are not necessarily based on extreme events. The probability for any number of exceedences during the design period can be computed by the binomial equation. Riggs computed these additional proba- bilities for several sizes of events and for five design periods (table 3 ). Whereas the probability of not exceeding 700 cubic feet per square mile once in the next 10 years is 0.5 , the probabilities of experiencing exactly 1,2 , or 3 years with accumulations greater than 700 cubic feet during this period are 0.36 , 0.12 , and 0.02 , respectively. It can also be seen that the probability of three or more exceedences during the next 10 years is 0.02 .

Table 3.--Probability of exceedence of various events for five design periods (Riggs 1961)

\begin{tabular}{|c|c|c|c|c|c|c|c|c|c|c|}
\hline \multirow{2}{*}{$\begin{array}{l}\text { Design } \\
\text { period } \\
\text { in } \\
\text { years }\end{array}$} & \multirow{2}{*}{$\begin{array}{l}\text { Recurrence } \\
\text { interval of } \\
\text { event from } \\
\text { frequency } \\
\text { curve }\end{array}$} & \multirow{2}{*}{$\begin{array}{c}\text { Probability } \\
\text { of } \\
\text { exceedence } \\
\text { in l year }\end{array}$} & \multicolumn{8}{|c|}{ Number of exceedences during design period } \\
\hline & & & 0 & 1 & 2 & 3 & 4 & $\begin{array}{c}1 \\
\text { or } \\
\text { more }\end{array}$ & $\begin{array}{c}2 \\
\text { or } \\
\text { more }\end{array}$ & $\begin{array}{c}3 \\
\text { or } \\
\text { more }\end{array}$ \\
\hline 2 & 2.0 & 0.500 & 0.25 & 0.50 & 0.250 & & & 0.75 & 0.25 & \\
\hline 2 & 3.4 & .293 & .50 & .41 & .086 & & & .50 & .09 & \\
\hline 2 & 7.5 & .134 & .75 & .23 & .018 & & & .25 & .02 & \\
\hline 5 & 4.13 & .242 & .25 & .40 & .255 & 0.082 & 0.0130 & .75 & .35 & 0.095 \\
\hline 5 & 5.0 & .200 & .33 & .41 & .205 & .051 & .0064 & .67 & .26 & .055 \\
\hline 5 & 7.8 & .129 & .50 & .37 & .110 & .016 & .0013 & .50 & .13 & .020 \\
\hline 5 & 17.8 & .056 & .75 & .22 & .026 & .002 & .0001 & .25 & .03 & .004 \\
\hline 10 & 7.7 & .130 & .25 & .37 & .250 & .100 & .0273 & .75 & .38 & .130 \\
\hline 10 & 10.0 & .100 & .35 & .39 & .194 & .057 & .0112 & .65 & .26 & .066 \\
\hline 10 & 14.9 & .067 & .50 & .36 & .116 & .022 & .0028 & .50 & .14 & .024 \\
\hline 10 & 35.7 & .028 & .75 & .22 & .028 & .002 & .0001 & .25 & .03 & .002 \\
\hline 20 & 14.9 & .067 & .25 & .36 & .245 & .105 & .0319 & .75 & .39 & .145 \\
\hline 20 & 20.0 & .050 & .36 & .38 & .189 & .059 & .0133 & .64 & .26 & .071 \\
\hline 20 & 29.4 & .034 & .50 & .35 & .118 & .025 & .0028 & .50 & .15 & .032 \\
\hline 20 & 71.0 & .014 & .75 & .21 & .030 & .003 & .0002 & .25 & .04 & .010 \\
\hline 40 & 29.4 & .034 & .25 & .35 & .242 & .110 & .0352 & .75 & .40 & .158 \\
\hline 40 & 40.0 & .025 & .36 & .37 & .185 & .060 & .0143 & .64 & .27 & .085 \\
\hline 40 & 59.0 & .017 & .50 & .34 & .118 & .026 & .0041 & .50 & .16 & .042 \\
\hline 40 & 139.0 & .007 & .75 & .21 & .030 & .003 & .0002 & .25 & .04 & .010 \\
\hline
\end{tabular}




\section{Summary and Conclusions}

Annual sediment yields were studied from one carefully logged and two undisturbed watersheds in the Fraser Experimental Forest, Colorado. The watersheds were described in part by evaluation of selected geomorphic characteristics.

The watersheds are very stable and characterized by coarse drainage texture and mature topography. The profiles of the main channels indicate they are in a graded condition. Results of particle-size analyses indicate that trapped sediments can be classified into three distinct sediment groups:

1. Well graded gravel with little or no fines,

2. Poorly graded sand with little or no fines, and

3. Silty or fine sand.

The coarse nature of the trapped sediments and observations of suspended sediment during peak flows (less than 5 p.p.m. in 1964 and 1965) indicate that the trap efficiencies of the debris basins are very nearly 100 percent.

A good correlation exists between annual peak discharge and annual accumulated sediment on all three watersheds. Sediment yields from these watersheds are also highly correlated with total annual flows. The relationships indicate that a major portion of the total sediment load is composed of bed material derived from streambank erosion and channel degradation. This conclusion is also supported by the low suspended-sediment concentration observed at the outflow of each debris basin during peak streamflow.

Sediment yields from the logged watershed were relatively large during the years immediately after treatment. Yields in subsequent years have been considerably less even though the average annual increase in streamflow has been about 25 percent since cutting。 Mean annual sediment yields from the three watersheds were compared statistically for the period 1956 through 1963. Differences between means were not significant.

Magnitude-frequency relationships based on combined data from two of the three watersheds were developed for estimating longterm sediment yields. The design period con- cept shows that on a long-term basis, significant accumulations of sediment can be expected at a diversion point.

\section{Literature Cited}

Brune, Gunnar M.

1953. Trap efficiency of reservoirs. Trans. Amer. Geophys. Union 34: 407-417. Horton, Robert E.

1945. Erosional development of streams and their drainage basins; hydrophysical approach to quantitative geomorphology. Bull. Geol. S Soc. Amer. 56: 275-370.

Martinelli, M. Jr.

1964. Watershed management in the Rocky Mountain alpine and subalpine zones** U.S. Forest Serv. Res. Note RM-36, 7 pp., illus. Rocky Mountain Forest and Range Exp. Sta., Ft. Collins, Colo.

Moore, C. M., Wood, W. J., and Renfro, G. W. 1960. Trap efficiency of reservoirs, debris basins, and debris dams. J.Hydraul., Div. Amer. Soc. Civil Eng., 86(HY2): 69-87.

Retzer, John L.

1962. Soil survey of Fraser alpine area, Colorado. U.S. Dep. Agr. and Colo. Agr. Exp. Sta., Ser. 1956, No. 20, 47 pp., illus. Washington, D.C.: U.S. Government Printing Office.

Riggs, H. C.

1961. Frequency of natural events. J. Hyddraul., Div. Amer. Soc. Civil Eng., 87(HY1): 15-26.

Schumm, S. A.

1956. Evolution of drainage systems and slopes in badlands at Perth Amboy, New Jersey. Bull. Geol. Soc. Amer. 67: 597-646.

Strahler, Arthur N.

1957. Quantitative analysis of watershed geomorphology. Trans. Amer. Geophys. Union 38: 913-920.

U. S. Bureau of Reclamation.

1960. Earth manual. 451 pp., Washington, D.C.: U.S. Government Printing Office.

*Address requests for copies to the originating office. 



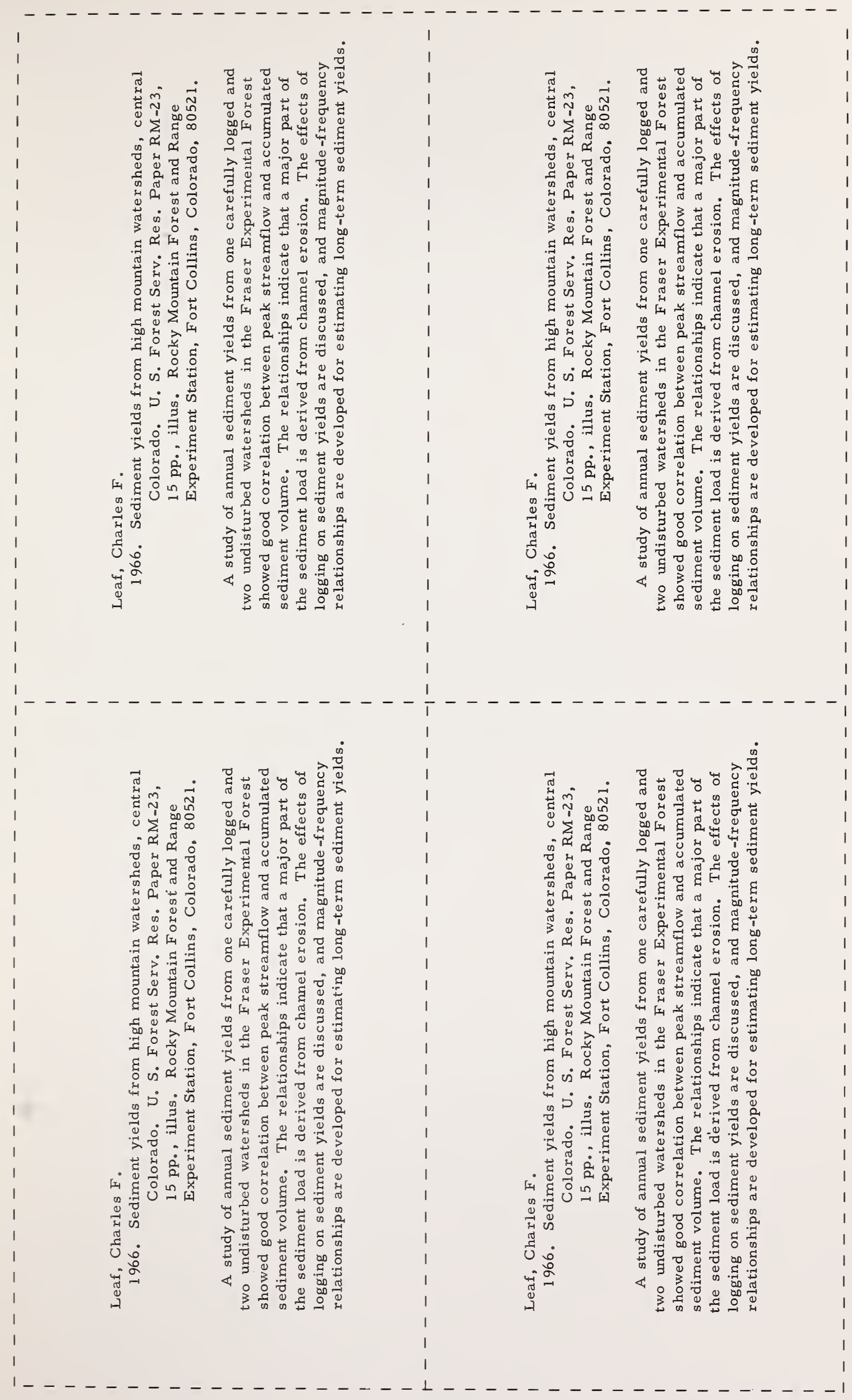




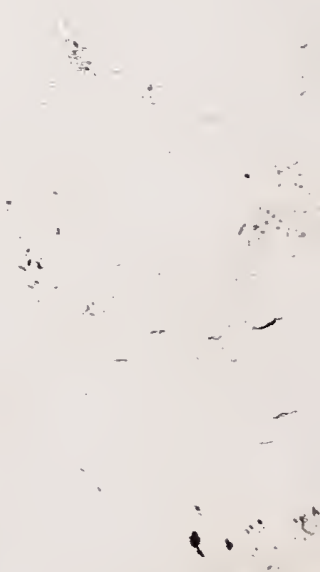

? 